\title{
A Study on the Relationships Between Burnout Status and Organizational Commitment
}

\author{
Unal Demirtas*, Mehmet Cetin, Gultekin Ozturk, Yusuf Ziya Turk and Turan Fedai \\ Gulhane Military Medical Academy, Ankara, Turkey
}

\begin{abstract}
Despite the fact that; there are various studies that have been performed on burnout syndrome and organizational commitment; number of studies that focus on the relationship between these two concepts is rather low. Target population of this includes 105 active duty health officers who have been serving under the roof of Turkish Armed Forces for more than 10 years in Ankara. The survey form is designed to include demographical features of participants, "Maslach Burnout Inventory" (MBI) and "Continuance and Affective Commitment Scale" of Mayer and Allen. When burnout levels are evaluated according to demographical features; active duty health officers who are graduated from $\mathrm{NCOHC}$, serve in the military quarters and married with children, are found out to have higher scores in terms of affective burnout dimension and depersonalization sub-dimension. When affective burnout levels are evaluated according to location of duty; officers who work in military quarters have been found to have a higher affective burnout score; which has also been discovered to be statistically relevant as well $(p=0,033)$. This study has been evaluated to be a beneficial contribution for future regulations which may intend to increase the overall morale and motivation, decrease the organizational burnout and increase the organizational commitment.
\end{abstract}

\section{Introduction}

Today, we witness a time where fundamental changes occur involving problems that influence the mental status of the employee. Stress and burnout have been accepted as the epidemics of the modern society. Their importance have been acknowledged throughout the world, especially in term of their impact on physical health and inability to work $[1,2]$. Fredeunberg has asserted the first opinions about the concept of burnout in 1974 [2].

Reasons of burnout are divided into two groups such as personal facts and institutional facts. While age, gender, marital status, education, personality, expectations and lack of education are regarded as the personal facts; extreme work load, changes in the workplace environment, conflict / uncertainty of roles, features of the working environment, duration of work, lack of supervision, relationships and conflicts with other colleagues, lack of professional feedback and communication can be listed as the institutional facts [3-6].

The studies on burnout syndrome is especially important due to facts such as; the spread nature of burnout and its social, economic and humane burden on societies and individuals; the importance of pre-emptively intercepting and avoiding the influence of burnout syndrome before the occurrence of first symptoms and the ability to avoid and prevent from burnout syndrome by enhancing the overall quality of health $[2,5,6]$. Christina Maslach and Jackson, who are recognized as a pioneer of this field; have published the first version of Professional Burnout Inventory in 1981. This inventory has been used as the "golden standard" for measuring burnout syndrome $[2,7,8]$.

When the concept of "commitment" is taken into consideration; first of all, its brief definition can be accepted as "the power that influences and pushes the individual towards a certain target or goal" $[9,10]$. Institutional or organizational commitment is, on the other hand, defined as the "emotional and sensual commitment to goals and values of an organization which are perceived and acknowledged differently than the individual role of the person according to his/ her personal goals, values and benefits. The pillars of institutional commitment are usually listed as; believing and accepting the goals and values of an organization, striving and make all possible endeavors for the benefit of the organization and feeling a continuous desire to sustain the membership inside that organization $[11,12]$. Institutional commitment, as a concept, continues to increase its popularity in the literature especially in terms of its influence on organizational and institutional psychology. The first studies on organizational commitment have considered organizational commitment as a mono-dimensional concept. On the other hand, there have been other approaches and studies which address this concept in terms of behavioral, attitudinal and normative commitment $[13,14]$. Sometimes, organizational and professional commitment can be confused with each other. While organizational are more important in terms of organizational commitment, professional commitment is generally influenced by personal facts [3,11]. Organizational commitment has been analyzed by Meyer and Allen under two titles, such as commitment to continuance and normative commitment. At later stages, normative commitment has been added and a three-phased organizational commitment structure has been developed [11,15]. When a literature scan is performed involving burnout syndrome and organizational commitment; several studies can be found:

These studies can be listed as; Ergin's study which involve burnout syndrome in physicians and nurses and adaptation of Maslach Burnout Scale; Dogan's study which focus on burnout status of healthcare personnel and relevant influential elements; Burnout research of Kalemoglu and Keskin which have been performed to evaluate the burnout status of 44 healthcare personnel including 22 emergency service personnel in GMMA (Gulhane Military Medical Academy); study of Ashtari, Farhady and Khodaee research on relationship between job burnout and work performance in a sample of Iranian

*Corresponding author: Unal Demirtas, Gulhane Military Medical Academy, Ankara, Turkey, Tel: 9054125780009; E-mail: drunalde@gmail.com

Received March 26, 2015; Accepted April 21, 2015; Published April 28, 2015

Citation: Demirtas U, Cetin M, Ozturk G, Turk YZ, Fedai T (2015) A Study on the Relatıonshıps Between Burnout Status and Organızational Commitment. J Psychiatry 18: 284 doi: 10.4172/2378-5756.1000284

Copyright: @ 2015 Demirtas U, et al. This is an open-access article distributed under the terms of the Creative Commons Attribution License, which permits unrestricted use, distribution, and reproduction in any medium, provided the original author and source are credited 
mental health staff, Okray Kocabıyık and Cakıcı's studies on burnout and professional satisfaction status of healthcare personnel, study of Kokonya et.al on burnout syndrome among medical workers at Kenyatta National Hospital (KNH), Nairobi, Kenya; Ozturk et al. study on practitioner and specialist physicians who admit to their training unit to perform their military services as physicians; Study of Yavuzyllmaz et al. on burnout and professional satisfaction status of healthcare personnel as well as relevant factors in state dispensers in central Trabzon province; study of Gunes, Bayraktaroglu and Kutanis on the relations between burnout levels and organization commitment of the administrative personnel in a state university and doctorate thesis of Yildiran involving professional and organizational commitment levels of active duty officers and influence of the quality of life on professional satisfaction and the desire to leave work [12,16-24].

\section{Aim of this Study}

Despite the fact that; there are various studies that have been performed on burnout syndrome and organizational commitment; number of studies that focus on the relationship between these two concepts is rather low. Therefore; this study aims to designate the burnout and organizational commitment level of active duty health officers in Turkish Armed Forces, an organization with a deeprooted organizational culture, while evaluating the organizational commitment levels in the organization, lighting the way for the efforts which intends to decrease the organizational burnout and increase the commitment as well as contributing future regulations to increase the institutional morale and motivation.

\section{Materials and Methods}

Target population of this definitive-type study includes 105 active duty health officers who have been serving under the roof of Turkish Armed Forces for more than 10 years in different hospitals, barracks, and institutions of the organization in Ankara. Normally, a sample is not selected in descriptive research so a study sample has not been selected and the study has been performed by means of the survey forms which have been applied to the entire population. We selected Ankara for this study because we could contact personnel who serve in hospital, military quarters and troop. Inclusion criteria are to volunteer for complete questionnaire. Ethical consent was obtained. The first section of the survey form is designed to include the questions which intend to evaluate the demographical features of participants. In the second section of the study, "Maslach Burnout Inventory" (MBI) has been used to designate the burnout levels of active duty health officers; under different subtitles such as affective burnout, depersonalization and individual success. At the third section of the survey; "Continuance and Affective Commitment Scale" of Mayer and Allen has been used to evaluate the organizational commitment levels of the participants. Maslach Burnout Inventory is a 5-Likert type self-feedback scale which includes 22 questions. At the affective burnout sub-dimension of the scale; feelings of the individual involving excessive professional burdens and burnout are defined while depersonalization subdimension of the scale defines behaviors and attitudes of the individual towards others who receive his/her service in such a way which lacks any sense or emotion. On the other hand, the third success sub-dimension of the scale defines the ability and satisfaction of the individual which involve his/her success rate over difficulties. MBI includes 9 questions to measure the affective burnout level, 5 questions to measure depersonalization and 8 questions to measure individual success. Affective burnout (score interval 0-36) and depersonalization (score interval $0-20$ ) sub-scale scores are given points 0 to 4 as if 0 for never and 4 for always. Individual success (score interval 0-32) sub-dimensional score on the other hand is graded vice versa. Only scores from sub-dimensions are taken into consideration for grading the total score as a calculation of scores acquired from MBI does not involve a breakpoint. Therefore; level of burnout can be accepted to be proportionally high to the scores that have been acquired from the sub-dimensions of MBI. In Continuance and Affective Commitment Scale, 8 questions have been provided each for affective commitment and continuance-related commitment measurements. The questions are graded between 1-5 points. Score interval is given between 0 to 40. A higher score is deemed to be indicating a higher commitment for the organization. SPSS software (SPSS for Windows 15.0) has been used to analyze the data. Relevance of affective burnout, personal success, depersonalization scores as well as affective commitment and continuance commitment scores to normal distribution has been evaluated by using kolmogorov-smirnov test and found that data do not fit normal distribution. Therefore; Mann-Whitney $U$ and Kruskal Wallis tests have been used for evaluating the data, rather than parametric tests. Statistical relevance level has been accepted as $\mathrm{p}<0.05$.

\section{Results}

Demographical features and professional features of active duty officers who take part in the study; as well as scores acquired from Maslach Burnout Inventory and statistical analysis results have been given in Table 1. Following the reliability tests of the MBI which has been used in the study; Cronbach alpha values has been found to be 0.88 for affective burnout, 0.74 for depersonalization sub dimension and 0.7 for personal success sub dimension. According to these results, burnout inventory can be accepted to be reliable.

As also shown in Table 1; ages of the participant active duty officers range from 25 to 35 with a mean age average of 29.01. All participants are male; 80 of whom are married, 65 of whom have children, and 80 of whom are graduated from Gülhane Military Medical Academy Non-commissioned Officer Health College (NCOHC). 67 of these participating officers serve in detachments. Burnout levels (affective burnout, depersonalization and personal success) and organizational commitment (affective commitment and commitment to continuance) are analyzed to find out whether they are related to age, gender, marital status, number of children, graduated institution and location of duty. When burnout levels are evaluated according to demographical features; active duty health officers who are graduated from NCOHC, serve in the military quarters and married with children, are found out to have higher scores in terms of affective burnout dimension and depersonalization sub-dimension. In terms of personal success sub dimension, active duty officers who are single, between 25-30 years of age, do not have children, graduated from non-military schools and serve in military quarters are found to have a higher score. Following the statistical analyses which have been performed to determine whether burnout levels of active duty health officers show a meaningful differences according to demographical variables; marital status and having children are found to be non-influential in terms of burnout levels. When affective burnout levels are evaluated according to location of duty; officers who work in military quarters have been found to have a higher affective burnout score; which has also been discovered to be statistically relevant as well $(\mathrm{p}=0,033)$.

Affective commitment, continual commitment and status of these commitment factors according to demographical and professional features for participating active duty health officers are given in Table 2. Affective commitment and continuance commitment level 
Citation: Demirtas U, Cetin M, Ozturk G, Turk YZ, Fedai T (2015) A Study on the Relatıonshıps Between Burnout Status and Organızational Commitment. J Psychiatry 18: 284 doi: 10.4172/2378-5756.1000284

Page 3 of 5

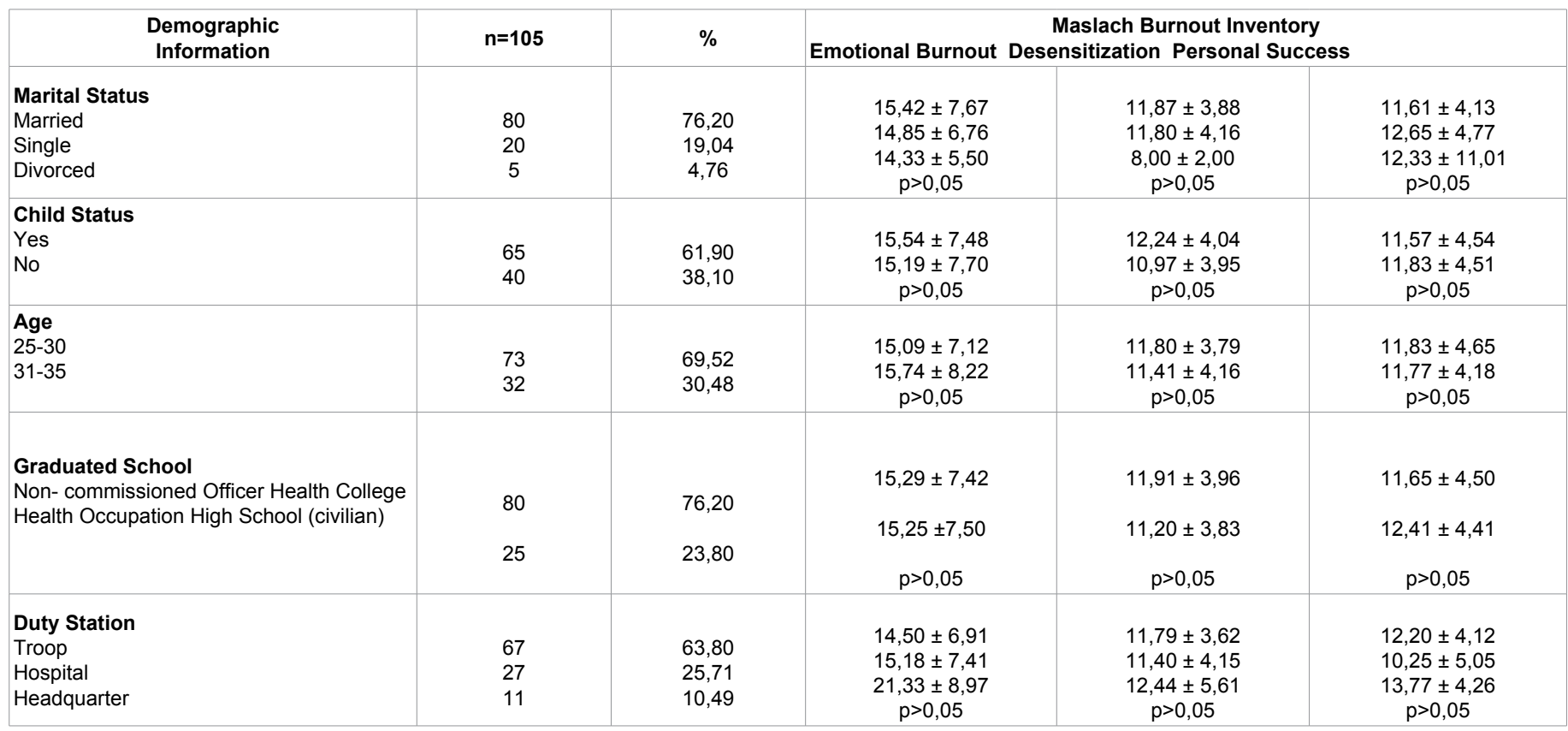

Table 1: Status of demographic features of active duty health officers according to maslach burnout inventory.

\begin{tabular}{|c|c|c|c|c|}
\hline \multirow{2}{*}{$\begin{array}{l}\quad \begin{array}{c}\text { Demographic } \\
\text { Information }\end{array} \\
\text { Marital Status } \\
\text { Married } \\
\text { Single } \\
\text { Divorced }\end{array}$} & \multirow{2}{*}{$\begin{array}{c}n=105 \\
\\
80 \\
20 \\
5\end{array}$} & \multirow{2}{*}{$\begin{array}{c}\% \\
\\
\\
76,20 \\
19,04 \\
4,76\end{array}$} & \multicolumn{2}{|c|}{$\begin{array}{c}\text { Continuance and Affective Commitment Scale } \\
\text { Duygusal Bağlılık Devamlılık }\end{array}$} \\
\hline & & & $\begin{array}{c}2,01 \pm 0,46 \\
1,88+0,31 \\
2,16+0,19 \\
\mathbf{p}>\mathbf{0 , 0 5}\end{array}$ & $\begin{array}{l}1,76 \pm 0,50 \\
1,76+0,48 \\
1,50+0,45 \\
p>0,05\end{array}$ \\
\hline $\begin{array}{l}\text { Child Status } \\
\text { Yes } \\
\text { No }\end{array}$ & $\begin{array}{l}65 \\
40\end{array}$ & $\begin{array}{l}61,90 \\
38,10\end{array}$ & $\begin{array}{l}2,07+0,47 \\
1,90+0,37 \\
p>0,05\end{array}$ & $\begin{array}{l}1,75+0,50 \\
1,74+0,49 \\
p>0,05\end{array}$ \\
\hline $\begin{array}{l}\text { Age } \\
25-30 \\
31-35\end{array}$ & $\begin{array}{l}73 \\
32\end{array}$ & $\begin{array}{l}69,52 \\
30,48\end{array}$ & $\begin{array}{c}2,00+0,42 \\
1,97+0,47 \\
\mathbf{p}>0,05\end{array}$ & $\begin{array}{l}1,71+0,45 \\
1,84+0,60 \\
\mathbf{p}>\mathbf{0 , 0 5}\end{array}$ \\
\hline $\begin{array}{l}\text { Graduated School } \\
\text { Non- commissioned Officer Health } \\
\text { College } \\
\text { Health Occupation High School (civilian) }\end{array}$ & $\begin{array}{l}80 \\
25\end{array}$ & $\begin{array}{l}76,20 \\
23,80\end{array}$ & $\begin{array}{c}2,00+0,43 \\
1,95+0,45 \\
\mathbf{p}>\mathbf{0 , 0 5}\end{array}$ & $\begin{array}{c}1,70+0,47 \\
1,93+0,55 \\
\mathbf{p}>\mathbf{0 , 0 5}\end{array}$ \\
\hline $\begin{array}{l}\text { Duty Station } \\
\text { Troop } \\
\text { Hospital } \\
\text { Headquarter }\end{array}$ & $\begin{array}{l}67 \\
27 \\
11\end{array}$ & $\begin{array}{l}63,80 \\
25,71 \\
10,49\end{array}$ & $\begin{array}{l}1,95+0,41 \\
2,11+0,48 \\
1,91+0,40 \\
\mathbf{p}>\mathbf{0 , 0 5}\end{array}$ & $\begin{array}{c}1,74+0,48 \\
1,78+0,52 \\
1,76+0,58 \\
p>0,05\end{array}$ \\
\hline
\end{tabular}

Table 2: Status of demographic features of active duty health officers according to continuance and affective commitment scale ${ }^{*} p<0.05$, ${ }^{* *} p<0.01$.

of active duty health officers have been calculated to be 2.01 and 1.76 respectively. When affective commitment levels are taken into consideration; participants who are 25-30 years of age, have children, graduated from $\mathrm{NCOHC}$ and serve in hospitals have been found to have higher average score levels. Additionally participants who are 31-35 years of age, graduated from non-military schools and serve in hospitals have been found to have higher average score levels in terms of continuance commitment. School of graduation has been found to be influential in terms of affective commitment. Participants who have graduated from SAMYO, have been found to have a higher commitment score average than participants who have graduated from non-military schools. When continuance commitment is evaluated in terms of location of duty; participants who serve in the hospital have been found to have a higher commitment score than participants who serve in military quarters. Following the statistical analyses; subdimensional organizational commitment levels of active duty health officers have been determined to be lacking any meaningful difference in terms of their affective commitment and continuance commitment levels when demographical and professional features are taken into consideration.

Another object of this study has been designated as finding out whether a statistical correlation is present between burnout levels and commitment levels of active duty health officers. The results of the correlation analysis which has been performed for this purpose have 
been given in Table 3. According to these values; a positive-oriented weak correlation has been detected between continuance commitment and depersonalization between affective commitment and affective burnout. Absence of females in our survey population has been the most important restrictor of our study, object of which is to define the correlation between the burnout level and organizational commitment levels of active duty health officers.

\section{Discussion}

Mean scores of the active duty health officers in Maslach Burnout Inventory has been calculated to be 15,25 for affective burnout dimension, 11,74 for depersonalization dimension and 11,83 in personal success dimension. In the studies that have been performed by Walters et al. On medics and physicians who served in Iraq and Afghanistan; affective burnout, depersonalization and personal success scores of combat medics have been measured as 26,46; 12,50 and 34,15 respectively [25]. In the study of Kokonya et al. the prevalence rate of burnout syndrome among the Kenyatta Hospital medical workers was found high [21]. In the study of Kaya et al. on healthcare personnel; affective burnout score has been measured to be 14,63, personal success has been measured to be 10, 80 and depersonalization has been measured to be 4,02 [26]. Study of Ozturk et al. on physicians have calculated affective burnout score as 21,81 , depersonalization as 9 , 66 and personal success as 17, 35 [22]. In a similar study performed by Yavuzyilmaz et al. mean scores have been measured to be 14, 17 for affective burnout, 5,00 for depersonalization and 9,49 for personal success [23]. Similarly, the study of Kocabıyık and Çakıcı on physicians in two different hospitals have provided a lower mean score in terms of affective burnout $[11,24]$ and personalization dimensions $(7,05)$ while a higher mean score in personal success dimension [22,27]. Under the scope of our study; we have found that burnout level of single participants have been higher in terms of the relation between marital status personal success [12]. Similar findings can also be found in studies of Ozturk et al. [17], Yavuzyilmaz [13], Kocabiyik [20], and Sunter et al. $[6,20-23,28]$.

When mean scores according to age groups are taken into consideration, 21-35 age group has been found to have a higher affective burnout [15], while have a lower personal success level [11]. The studies of Kaya et al. have also designated that personal success score tends to go lower as the age increases, similar to our study [26]. In the study of Bugdayci et al., it has been found out that depersonalization and affective burnout scores tend to decrease as the age increases, while personal achievement score increases as the individual gets older, unlike out study [29]. This aforesaid study has provided results which are contrary to the literature. Participants who work in military quarters have been found to have a higher mean score in terms of affective burnout, depersonalization and personal

\begin{tabular}{|l|l|l|l|l|l|}
\hline & MBI-EB & MBI-DS & MBI-PS & CAC-AC & CAC-CC \\
\hline MBI-EB & 1,0 &, $512^{* *}$ &,$- 316^{* *}$ &, $237^{*}$ &, 13 \\
\hline MBI-DS &, $512^{* *}$ & $1,0^{* *}$ &,- 277 &, $206^{*}$ &, $204^{*}$ \\
\hline MBI-PS &,$- 316^{* *}$ &,$- 277^{* *}$ & 1,0 &,- 134 &,- 034 \\
\hline CAC-AC &, $237^{*}$ &, $206^{*}$ &,- 134 & 1,0 &, 096 \\
\hline CAC-CC &, 13 &, $204^{*}$ &,- 034 &, 096 & 1,0 \\
\hline
\end{tabular}

Table 3: Correlations among the scores of participants in certain scales ( $r$ ).

MBI-EB: Maslach Burnout Inventory-Emotional Burnout MBI-PS: Maslach Burnout Inventory -Personal Success MBI-DS: Maslach Burnout Inventory-Desensitization

CAC-AC: Continuance and Affective Commitment Scale -Affective Commitment CAC-CC: Continuance and Affective Commitment Scale -Continuance Commitment success when compared to the personnel who work in detachments and hospitals. Under the scope of our study, affective commitment and continuance commitment levels of active duty health officers have been calculated to be 2,01 and 1,76 respectively. Affective commitment level has been found to be 3,3 and continuance commitment level has been found to be 1,9 under the scope of the doctorate thesis performed by Yildiran involving professional and organizational commitment levels of active duty officers and influence of the quality of life on professional satisfaction and the desire to leave work [24]. Affective commitment and continuance commitment levels have been calculated to be 3,05 and 2,89 respectively in study of Gunes et al. and 2,96 and 2,94 respectively in the study of Top et al. [11,30]. The study that has been performed by Gider and Top in educational hospitals; the graduate thesis that has been performed on nurses working in Ankara GMMA Hospital and Gundogan's study on employee of the central bank, have all acquired higher results than our study $[11,31,32]$. Tetik's study on healthcare personnel has provided lower mean scores for affective commitment [1] and higher mean scores for continuance commitment $(2,50)$ than our study [33].

When affective commitment levels are evaluated in terms of age; participants in 25-30 age group have been found to have a lower organizational commitment $(2,00 \pm 0,42)$ than participants in $31-35$ age group $(1,97)$. This issue is found to be similar in studies of Gunes et al., Gundogan et al. and Agun [11,12]. When affective commitment is evaluated according to marital status, married participants $(2,01)$ have been found to have a higher organizational commitment than single [1] and divorced participants [2,16]. Studies of Gundogan, Agun, Gunes et al. have also observed the affective commitment to be higher for married participants [11,12].

Graduated school is also found to be influential. Participants who have graduated from $\mathrm{NCOHC}$ have been found to have higher affective commitment mean scores $(2,00)$ than participants who have graduated from non-military schools $(1,95)$. When commitment status is taken into consideration according to location of duty; participants who serve in hospitals have been found to have the highest commitment scores $(1,78)$ while participants who serve in detachments have a lower commitment mean score $(1,74)$. Study of Gundogan on central bank personnel have found that; branch personnel have a lower continuance commitment $(3,53)$ then the personnel who work in headquarters $(3,58)$ [11]. Similar to other certain studies in the literature, our study has not discovered a statistically meaningful difference between affective commitment and continuance commitment dimensions of organizational commitment and personal features of the participant such as age, marital status, education and location of duty ( $p>0.05)$.

\section{Conclusion}

Affective burnout, which can be defined as the state of exhaustion resulting from the current profession of the individual; has been found to be higher in active duty health officers who have graduated from Non-commissioned Officer Health College when compared to the officers that have graduated from non-military institutions. Likewise, affective burnout has been designated to be higher for officers who serve in military quarters when compared to others that serve in hospitals and detachments. Liking the profession is the most influential fact on organizational commitment. Generally, affective commitment is desired and required to be higher than the commitment to continuance. Affective commitment level has been found to be higher for participants who have graduated from $\mathrm{NCOHC}$ when compared to participants that have graduated from non-military institutions. 
Citation: Demirtas U, Cetin M, Ozturk G, Turk YZ, Fedai T (2015) A Study on the Relatıonshıps Between Burnout Status and Organızational Commitment. J Psychiatry 18: 284 doi: 10.4172/2378-5756.1000284

Page 5 of 5

Likewise, when compared to officers that serve in detachments or military quarters, the higher affective commitment level of active duty health officers who serve in hospitals, has been evaluated to be resulting from the professional satisfaction that have been experienced thanks to their increased ability to use the skills they had learned in their workplace and daily duty.

Consequently, this study has been evaluated to be a beneficial contribution for future regulations which may intend to increase the overall morale and motivation, decrease the organizational burnout and increase the organizational commitment with the help of other studies they will be performed on similar subjects.

\section{References}

1. Schaufeli WB, Leiter MP, Maslach C (2009) Burnout: 35 years of research and practice. Career Development International 14: 204-220.

2. Salla Toppinen-Tanner "Process of Burnout: Structure, Antecedents, and Consequences" People and Work Research Reports 93. Finnish Institute of Occupational Health, Helsinki, Finland 2011; 4-5.

3. Mesut Çimen (2000) "TSK Sağlık Personelinin Tükenmişlik, İ̧ Doyumu, Kuruma bağılık ve Iş̧ten Ayrılma Niyetleri Illişkin Bir Alan Araştırması" Gülhane Askeri Tıp Akademisi Doktora Tezi Ankara.

4. Tülin Tunc (2008) "Doktor ve Hemsirelerde Tükenmişlik ile Rol Catıșması ve Rol Belirsizliği Arasındaki İlişki: Bir Üniversite Hastanesi Örneği". Sakarya Üniversitesi Yüksek Lisans Tezi Mayıs.

5. Schaufeli WB (2003) Past performance and future perspectives of burnout research. South African Journal of Industrial Psychology 29: 1-15.

6. Shirom A (2009) Epilogue: mapping future research on burnout and health Stress and Health 25: 375-380.

7. Maslach C (2003) the cost of caring. Cambridge, MA: Malor Books.

8. Maslach CM, Jackson SE (1981) The measurement of experienced burnout Journal of Occupational Behavior 2: 99-113.

9. Meyer J, Herscovitch L (2001) Commitment in the workplace: Toward a general model. Human Resource Management Review 11: 299-326.

10. Çetin $M$ ve ark (2012) "Hekimlerin Mesleki Bağlllık Düzeylerini Etkileyen Faktörlerin Incelenmesi. Anatol J Clin Investig 6: 220-224

11. Tamer G, Örgütsel B (2009) Türkiye Cumhuriyet Merkez Bankası Uygulaması" Uzmanlık Yeterlilik Tezi, Türkiye Cumhuriyet Merkez Bankası İnsan Kaynakları Genel Müdürlüğü Ankara, Eylül.

12. Ilkay G, Serkan B, Rana OK (2009) "Çalışanların Örgütsel Bağlıık ve Tükenmişlik Düzeyleri Arasındaki Iliş̧i: Bir Devlet Üniversitesi Örneğii Süleyman Demirel Üniversitesi İktisadi ve İari Bilimler Fakültesi Dergisi Y. C. 14, S.3 s.481-497.

13. Guatam T, Rolf VD, Ulrich W, Narottam U, Ann JD (2005) "Organizationa Citizenship Behavior and Organizational Commitment in Nepal", Asian J Soc Psychol 8: 305-314.

14. Meyer JP, David J, Stanley LH, Laryssa T (2002) "Affective, Continuance and Normative Commitment to The Organization: A Meta-Analysis of Antecedents, Correlates, and Consequences". J Voc Behav 61: 20-52.

15. Allen NJ, ve Meyer JP (1990) Organizational Commitment: Evidence of Career Stage Effects. Journal of Business Research, 26: 46-91.

16. Ergin C (1992) "Doktor ve Hemşirelerde Tükenmişlik ve Maslach Tükenmişlik Ölçeğinin Uyarlanması", VII.Ulusal Psikoloji Kongresi Bilimsel Çalışmaları, 2225 Eylül 1992, Hacettepe Üniversitesi, Türk Psikologlar Derneği Yayını, Ankara.

17. Doğan K (2005) Ankara'da Íki Eğitim ve Araştırma Hastanesinde Calışan Sağlık Personelinin Tukenmişlik Durumu ve Illişkili Etmenler. (Yayınlanmamış Yuksek Lisans Tezi). Ankara: Gazi Universitesi Sağlık Bilimleri Enstitusu, İsci Sağlığı ve Iş Guvenliği Ana Bilim Dalı.
18. Kalemoğlu MK (2006) Burnout Syndrome at The Emergency Service. ScandjTrauma Resusc Emerg Med 14: 37-40.

19. Z Ashtari, Y Farhady, MR Khodaee (2009) "Relationship between job burnout and work performance in a sample of Iranian mental health staff" Afr J Psychiatry 12: 71-74

20. Okray K, Z ve Çakıcı E (2008) Sağlık Çalışanlarında Tükenmişlik ve İş Doyumu Anadolu Psikiyatri Dergisi 9: 132-138.

21. Kokonya (2014) "Burnout Syndrome among Medical Workers at Kenyatta National Hospital (KNH) Nairobi Kenya" J Psychiatry 17: 6.

22. Gültekin O, Cetin M, Nuri Y, Yusuf ZT, Turan F (2012) "Hekimlerde Tükenmişlik Ve İş Doyumu Düzeyleri” Anatol J Clin Investig 6: 239-245.

23. Yavuzyılmaz A (2007) Burnout Syndrome, Job Satisfaction Levels and Related Factors in Central Trabzon Province Primary Health Center Workers. TAF Preventive Medicine Bulletin 6: 41-50.

24. Nuri Y (2010) "Muvazzaf Tabip Subayların Mesleki Ve Kurumsal Bağlııı Düzeyleriyle Çalışma Yaşam Kalitelerinin, İş Doyumu ve İşten Ayrılma Niyeti Üzerine Etkisinin İncelenmesi" GATA Askeri Sağlık Hizmetleri Programı Doktora Tezi, Ankara.

25. Kaya M (2007) ve ark. Birinci Basamak Sağlık Çalışanlarının Tükenmişlik Durumları, TSK Koruyucu Hekimlik Bülteni 6: 357-63.

26. Kocabıyık ZO, Çakıcı E (2008) Job Burn-out and Job Satisfaction in the Hospital Staff. Anatolian Journal of Psychiatry 9: 132-8.

27. Sünter AT, Canbaz S, Dabak S, Öz H, Pesken Y (2006) Pratisyen hekimlerde tükenmislik, ise baglı gerginlik ve is doyumu düzeyleri. Genel Tıp Dergisi 16 9-14.

28. Bugdaycı R, Kurt AÖ, Sasmaz T, Öner S (2005) Mersin ilinde görev yapan pratisyen ve uzman hekimlerde ruhsal tükenmislik durumu ve etkileyen faktörler. Saglık ve Toplum Dergisi 15: 25-31.

29. Gider Ö, Mehmet TOP, "Eğitim Ve Araştırma Hastanelerinde Çalışan Hekimlerin Örgütsel Bağlılık, Örgütsel Güven Ve İş Doyumu Düzeylerinin İncelenmesi" T.C. Sağlık Bakanlığı Tedavi Hizmetleri Genel Müdürlüğü II. Uluslar arası Sağlıkta Performans ve Kalite Kongresi Bildiriler Kitabı Cilt 2 ANKARA- 2010.

30. M. TOP ve ark. "Hastane İnsan Kaynaklarında Dönüşümcü Liderlik, Örgütsel Bağlılık, İ̧ Doyumu ve Örgütsel Güven Araştırması"

31. "Hemşirelerde İş Tatmini ve Örgütsel Bağlılık İlişkisi: GATA Hastanesi'nde Bi Uygulama" Yüksek Lisans Tezi, Atılım Üniversitesi Sosyal Bilimler Enstitüsü Sağlık Kurumları İşletmeciliği Anabilim Dalı Ankara 2011

32. Semra T, "Sağlık Çalışanlarının Örgütsel Bağlııı Düzeylerini Belirlemeye Yönelik Bir Araştırma", Sosyal ve Beşeri Bilimler Dergisi, Cilt 4, No 1, 2012.

33. Hazel A (2012) "Örgütsel Güven ile Örgütsel Bağlılık Arasındaki Illişki Üzerine Bir Araştırma" Yüksek Lisans Tezi, Marmara Üniversitesi Sosyal Bilimler Enstitüsü Çalışma Ekonomisi Ve Endüstri İlişkileri Anabilim Dalı İstanbul. 